\title{
Early Nutritional Interventions with Zinc, Selenium and Vitamin D for Raising Anti-Viral Resistance Against Progressive COVID-19
}

\author{
Jan Alexander ${ }^{1}{ }^{3}$, Alexey Tinkov ${ }^{2,3}$, Tor A. Strand ${ }^{4,5}$, Urban Alehagen ${ }^{6, *}$, Anatoly Skalny ${ }^{2,3}$ \\ and Jan Aaseth 3,5 (D) \\ 1 Division of Infection Control and Environment Health, Norwegian Institute of Public Health, \\ P.O. Box 222 Skøyen, 0213 Oslo, Norway; Jan.Alexander@fhi.no \\ 2 Laboratory of Biotechnology and Bioelementology, Yaroslavl State University, Sovetskaya Str. 14, \\ Yaroslavl 150000, Russia; tinkov.a.a@gmail.com (A.T.); skalny3@gmail.com (A.S.) \\ 3 IM Sechenov First Moscow State Medical University (Sechenov University), Bolshaya Pirogovskaya St., \\ Moscow 119146, Russia; jaol-aas@online.no \\ 4 Centre for International Health, University of Bergen, P.O. Box 7804, 5020 Bergen, Norway; tors@me.com \\ 5 Research Department, Innlandet Hospital Trust, P.O. Box 104, 2381 Brumunddal, Norway \\ 6 Division of Cardiovascular Medicine, Department of Medical and Health Sciences, Linköping University, \\ SE-58185 Linköping, Sweden \\ * Correspondence: urban.alehagen@liu.se; Tel.: +46-70-7915522
}

Received: 16 July 2020; Accepted: 5 August 2020; Published: 7 August 2020

\begin{abstract}
Objectives: The novel coronavirus infection (COVID-19) conveys a serious threat globally to health and economy because of a lack of vaccines and specific treatments. A common factor for conditions that predispose for serious progress is a low-grade inflammation, e.g., as seen in metabolic syndrome, diabetes, and heart failure, to which micronutrient deficiencies may contribute. The aim of the present article was to explore the usefulness of early micronutrient intervention, with focus on zinc, selenium, and vitamin D, to relieve escalation of COVID-19. Methods: We conducted an online search for articles published in the period 2010-2020 on zinc, selenium, and vitamin D, and corona and related virus infections. Results: There were a few studies providing direct evidence on associations between zinc, selenium, and vitamin D, and COVID-19. Adequate supply of zinc, selenium, and vitamin D is essential for resistance to other viral infections, immune function, and reduced inflammation. Hence, it is suggested that nutrition intervention securing an adequate status might protect against the novel coronavirus SARS-CoV-2 (Severe Acute Respiratory Syndrome - coronavirus-2) and mitigate the course of COVID-19. Conclusion: We recommended initiation of adequate supplementation in high-risk areas and/or soon after the time of suspected infection with SARS-CoV-2. Subjects in high-risk groups should have high priority as regards this nutritive adjuvant therapy, which should be started prior to administration of specific and supportive medical measures.
\end{abstract}

Keywords: COVID-19; corona virus; nutritional; therapy; micronutrients; selenium; zinc; vitamin A; vitamin $\mathrm{D}$; coenzyme $\mathrm{Q}_{10}$

\section{Introduction}

The novel coronavirus SARS-CoV-2 (Severe Acute Respiratory Syndrome-coronavirus-2), causing COVID-19, is by far the most dangerous coronavirus ever identified, capable of infecting not only animals, but also humans across the globe. The severity of the COVID-19 pandemic has dramatically surpassed the prevalence of acute respiratory syndrome coronavirus (SARS-CoV) and Middle East respiratory syndrome coronavirus (MERS-CoV), which were distributed to more limited regions in 2003 
and 2012, respectively. A single-stranded RNA comprises the genomic structure of SARS-CoV-2 [1]. In severe cases, COVID-19 is accompanied by excessive activation of the innate immune system with progressive inflammation and a cytokine storm from activated cells, particularly in the airways [2], leading to the cytokine release syndrome [3,4]. Unfortunately, in spite of their anti-inflammatory effects, corticosteroids have been observed to worsen the clinical status of patients with SARS or related virus infections [5,6]. Use of convalescent plasma has been tried as a possible approach, but the experiences with this strategy are limited [7]. Except for the use of convalescent plasma, there is at present no approved treatment or vaccine for COVID-19. Therefore, it is an urgent need for public health measures, not only to limit the spread of the virus, but also to implement preventive approaches to alleviate severe COVID-19, e.g., by reduction of the excessive inflammation. The metabolic status of the host, as influenced by advanced age, current medical condition, and lifestyle, appears to determine the clinical severity of COVID-19 [8]. In critically ill patients, coexisting diseases include type 2 diabetes, hypertension, and heart disease [9]. The elderly are more prone to severe respiratory infection than young people, apparently due to connections between old age and deficient nutrition and immunity [10]. Clinical and subclinical micronutrient deficiencies common in older adults are known to contribute to decreased immune function and age-related diseases [11], implying that nutritional management is essential to reduce the risk of severe infection [12]. In view of a lack of clinical data on preventive and/or therapeutic efficiency of the nutritive adequacy of selenium, zinc, and vitamin D in COVID-19, we, in the present narrative review, discussed recent clinical data on the role of these micronutrients in the protection against bronchopulmonary infections, as well as the existing indications of their impact on COVID-19. Although the status of other nutrients, such as vitamins C and A, may also play a role, they were not focused upon in the present article. We did a literature search for the period 2010-2020 on PubMed, Medline, and Google Scholar with the keywords of SARS, SARS-CoV-2, COVID 19, coronavirus, micronutrients (zinc, selenium, vitamin D), immune system, inflammation, prevention, and treatment. Based on the information retrieved, we here discussed the role of the nutritional status of certain trace elements and vitamin $\mathrm{D}$ in the perspective of principles for implementing preventive measures against RNA viruses.

\section{Nutritional Interventions as a Preventive Approach}

Clinical or subclinical micronutrient deficiencies, such as deficiencies of zinc, selenium, and vitamin D, which frequently occur in old age groups, contribute to age-related diseases including diabetes, hypertension, and coronary heart disease [13-15]. These diseases, which in a substantial fraction of the cases are related to the metabolic syndrome [16], are characterized by signs of low-grade inflammation, which may also result from ageing [17]. Pre-infectious signs of inflammation, such as elevated values for CRP (C-reactive protein), represent a common aggravating factor in COVID-19 [9]. Adequacy of zinc, selenium, and vitamin D is essential for adequate immunocompetence, which to some extent may counteract an inflammatory aggravation. Dietary advice alone may not be sufficient to secure adequacy for these nutrients in certain conditions, including in elderly subjects [18], involving the need for supplements in susceptible segments of populations.

\subsection{Zinc}

Being an essential component of numerous enzymes, such as superoxide dismutase 1 and 3 [19], the trace metal zinc is important for the development and maintenance of immune and other cells [20]. Zinc deficiency is known to result in dysfunctional humoral and cell-mediated immunity [21]. In the elderly, low Zn status (serum $\mathrm{Zn}$ values $<0.7 \mathrm{mg} / \mathrm{L}$ ) has been found to represent a risk factor for pneumonia [22]. Long-term zinc deficiency is known to increase inflammations and inflammatory biomarkers [23]. Most facets of the immune system are affected by zinc deficiency, particularly the T-cell function. Zinc deficiency also drives a Th17 response, which is associated with increased inflammation [24]. In elderly subjects, reduced concentrations of circulating zinc correlated with increased levels of the cytokines IL-6 (interleukine-6), IL-8, and TNF- $\alpha$ (Tumour necrosis factor- $\alpha$ ) [25]. 
In a case report, four COVID-19 outpatients 26-63 years of age were treated with lozenges of zinc salts [26]. They took the lozenges several times each day, up to doses between 115 to $184 \mathrm{mg}$ $\mathrm{Zn} /$ day for 10 to 14 days, and all of these patients recovered. In another case report, three COVID-19 patients 38-74 years of age with additional gut manifestations received zinc sulphate (220 $\mathrm{mg}$ Zn daily for 5 days), together with hydroxychloroquine and azithromycine [27]. The latter patients recovered. Being case reports, it was not possible to conclude on the efficacy of zinc.

With regard to other infectious diseases, many studies show that zinc status may impact the outcome. Several randomized control trials (RCTs) showed that zinc given during an acute episode of diarrhea reduces the duration and risk of persistent disease [28]. The World Health Organization therefore changed their recommendations for the treatment of childhood diarrhea to include oral zinc medication. Zinc also plays a role in acute respiratory infections [29]. Routine zinc supplementation reduces the incidence of acute lower respiratory infections in young children in low- and middle-income countries [30]. Several recent studies used zinc as an adjunct treatment for lower respiratory infections, although with mixed results [31]. In one large RCT from India enrolling young infants with signs of severe bacterial illness, it was investigated whether zinc could reduce the risk of treatment failure [32]. The authors found that children assigned to the zinc group had a $40 \%$ reduction in treatment failure and mortality compared with the placebo group. Many RCTs examined the role of zinc supplementation in common colds, the results from these showing that, when given early in the illness, zinc had the potential to reduce the duration by 1 to 3 days [33-35]. Furthermore, a positive effect of zinc supplementation was observed in several studies on hepatitis $C$, which is induced by infection with a single-stranded RNA virus [36]. In this context, it is of interest that raising the intracellular concentration of zinc with zinc-ionophores like pyrithione or chloroquin could directly reduce the replication of a variety of RNA viruses in cells in vitro through inhibition of their RNA polymerase activity [37]. Combined administration of zinc and pyrithione, even at low concentrations, inhibited the replication of SARS coronavirus (SARS-CoV) in vitro [38]. Consequently, zinc supplement may have effects, not only on the COVID-19-associated over-active inflammation, but presumably also on the SARS-CoV-2 agent itself [39]. As for the preventive doses used, it was noted that, on a long-term basis, an intake $\leq 25 \mathrm{mg} /$ day was recommended, as a high intake of zinc may disturb copper balance [40].

\subsection{Selenium}

Selenium is an essential trace element for mammalian redox biology by occurring as selenocysteine in catalytical centers of many selenoproteins [41,42]. An adequate supply of the amino acid serine is required for the synthesis of selenocysteine, which is incorporated into selenoproteins [43]. Nutritional deficiencies of selenium may impact, not only the immune response, but also the pathogenicity of a virus [44-46].

Of note, a recent study from China reported an association between the cure rate of CoV-2-infected patients and selenium status, as deduced from city population hair selenium from cities outside Hubei, reflecting regions with poor and adequate selenium intakes [44]. In a study, selenium status (selenium and SELENOP) were significantly higher in surviving COVID-19 inpatients $(n=27)$ compared with non-survivors $(n=6)$ [45]. Further studies with control of confounding and clinical trials are necessary to confirm this association. Of particular interest is the finding that a main protease of SARS-CoV-2 responsible for the viral replication, interacts with the essential seleno-enzyme glutathione peroxidase1 (GPX1) [46,47], which is strongly dependent on adequate selenium supply. It is notable that the GPX mimic ebselen (a synthetic selenium compound) is a potent inhibitor of the SARS-CoV-2 main protease [48]. Bioinformatic screening of the SARS-CoV-2 gene signatures provided further evidence of protein interactions and antisense transcript mRNA-mRNA interactions occurring at selenocysteine-related insertions in RNA viruses [49].

Dietary selenium deficiency, together with increased oxidative stress in the host, can alter a viral genome from a normally mildly pathogenic virus into a highly virulent agent after its entrance into the host, which occurred with the Coxsackie 3B virus in Keshan disease in a selenium-deficient 
area in China [50]. It was proposed that Se deficiency could play a substantial role in the genesis of SARS-CoV [51]. The potential protective effect of selenium is explained by its role as an essential cofactor in a group of enzymes that, in concert with vitamin E, works to reduce the formation of reactive oxygen species (ROS). ROS in excess may trigger oxidative changes both in invading microorganisms and in the cells in the host [52].

A failing antioxidant defense might also be accompanied by an exaggerated inflammatory response in the host, even in the absence of an active infection [53]. Among the most potent antioxidative selenoenzymes are the glutathione peroxidases (GPXs) and the thioredoxin reductases (TXNRDs), which need an intake of at least $100 \mu \mathrm{g}$ Se/day to function optimally.

Other selenoproteins, i.a., selenoprotein K (SELENOK) and selenoprotein S (SELENOS), also appear to play a role in the regulation of immune responses [54].

In a variety of infectious diseases selenium appears to play a significant role in protecting the respiratory system, in particular toward viral infections [54]. Beck et al. found that Se deficiency significantly increased the susceptibility to influenza-induced lung pathology associated with the overexpression of pro-inflammatory cytokines [55]. An analogous effect was observed in benign Coxsackie virus infection, which resulted in the development of myocarditis in Se-deficient mice [56]. These findings corresponded to the observation of lower interferon- $\gamma$ (IFN- $\gamma$ ) and TNF- $\alpha$ levels, as well as reduced survival rate in Se-deficient mice infected with the influenza virus as compared to Se-adequate controls [57]. In turn, selenium treatment was shown to up-regulate the expression of genes for interferons (IFN- $\alpha$, IFN- $\beta$, and IFN- $\gamma$ ) in response to the avian influenza (H9N2) virus [58].

In older adult humans, Se treatment was shown to modulate response to the influenza vaccination, being accompanied by increased IFN- $\gamma$ levels after vaccination [59]. Therefore, selenium supplementation to populations with suboptimal status has been considered a safe adjuvant therapy in preventive measures against viral infections [60]. The selenium status varies widely between different areas in the world. Compared with levels in Northern America [61], selenium levels in populations in large parts of Europe are well below a threshold of about $100 \mu \mathrm{g} / \mathrm{L}$ required for adequate expression of selenoproteins. The insufficient selenium intake is caused by low selenium content in soil and, consequently, in cereals and other food plants, as well as in fodder for grazing farm animals [41,62].

\subsection{Selenium Plus Cofactors}

The optimal function of the GPXs also depends upon adequate intracellular levels of the cofactor glutathione (GSH), explaining the importance of adequate intakes of proteins containing the sulfur component of this tripeptide, viz. cysteine or methionine. Reduced GSH is associated with senescence in several species, including humans [63]. Apparently healthy elderly people in the age group 60-79 had significantly lower erythrocyte GSH than younger individuals [64]. Moreover, individuals with chronic diseases, including hypertension, have a deficit of the active form of GSH $[65,66]$. In cases of marginal intakes of sulfur amino acids, supplementation with acetylcysteine will restore intracellular GSH levels, which is of crucial importance in bronchial and pulmonary cells [67]. N-acetylcysteine is already an approved and extensively used drug in obstructive bronchitis [68], and it has proven beneficial against severe influenza infection [69]. Administration of glutathione has been shown to relieve dyspnea associated with COVID-19 pneumonia [70].

Another factor co-operating with selenoenzymes appears to be coenzyme $\mathrm{Q}_{10}\left(\mathrm{CoQ}_{10}\right)$. In a Swedish randomized placebo-controlled study, healthy elderly subjects low in selenium were given selenium supplementation combined with coenzyme $Q_{10}$. This supplementation was shown to reduce the non-specific inflammatory response as measured by plasma CRP [71] and other biomarkers of inflammation [53], and also cardiovascular mortality [72]. As severe coronavirus infections are characterized by an overactive inflammation, this relief in inflammatory response by optimizing the selenium status is of considerable interest [62]. It is also relevant that $\mathrm{CoQ}_{10}$ supplements, even when given alone, can exert an anti-inflammatory effect [73]. An anti-inflammatory effect of exogenous $\mathrm{CoQ}_{10}$ may appear clearer in old age when its endogenous production is significantly reduced [74]. 
Selenium treatment given alone, without combination with acetylcysteine or $\operatorname{CoQ}_{10}$, in critical ill patients admitted to the intensive care unit (non-septic and septic patients) has been used [75]. In patients with advanced infections, Manzanares and coworkers [76], in a meta-analysis, did not find a consistent beneficial effect on mortality, but, in a subgroup analysis, they found a reduction in the infections in non-septic patients. When considering the positive effects of selenium on immune regulation and inflammation in populations low in selenium, it appears justified to conclude that an adequate pre-infectious status of selenium would represent a protective measure against the hyperinflammation characterizing corona viral infections. Thus, in subjects with suboptimal status (plasma selenium $<100 \mu \mathrm{g} / \mathrm{L}$ ), supplementation at a dose of 100-200 $\mu \mathrm{g}$ Se/day, with or without cofactors, to achieve rapid saturation of vital selenoproteins, should represent an adjuvant approach to prevent aggressive SARS-CoV-2 infection. However, a total long-term intake of selenium from food and supplements $\leq 300 \mu \mathrm{g}$ Se/day is recommended, as higher intakes may be associated with toxicity [77].

\subsection{Vitamin D}

It is well-known that cholecalciferol (vitamin D3) can be synthesized from cholesterol in the body skin upon exposure to sunlight. Its biological activity is dependent on successive hydroxylations by the liver and the kidneys to 1,2-(OH $)_{2}-\mathrm{D} 3$, which binds to vitamin D receptors. Beyond its roles in calcium homeostasis and the maintenance of bone integrity, it also stimulates the maturation of immune cells. Epidemiological studies suggested an inverse association between circulating levels of 25(OH)-D3, a biomarker of vitamin D status, and inflammatory biomarkers, including CRP and IL-6 [78]. Suboptimal levels of vitamin D, particularly at the end of the winter season, have been reported in a substantial number of otherwise healthy adults [79]. People with limited access to sunlight, and elderly with reduced synthesizing capacity, may have vitamin D deficiency [80].

Vitamin D has been suggested to play a role in COVID-19, as two ecological studies indicated that the rate of infection was higher in countries at higher latitudes and/or lower vitamin D status [81,82]. In a non-peer-reviewed study from Los Angeles, vitamin D deficiency was identified as a risk factor for positive COVID-19 tests [83]. A recent study on COVID-19 inpatients $(n=134)$ found that a significantly smaller fraction of patients in intensive care units had 25-OH-D above $50 \mathrm{nmol} / \mathrm{L}(19 \%)$ compared with those in conventional medical wards (39.1\%) [84]. In a non-peer-reviewed study from Cincinnati, the authors found associations between vitamin D deficiency and hospital admission, disease severity, and also with death, among patients from primary care and specialized clinics $(n=691)$ [85].

Vitamin D was shown to be an essential factor for protection against respiratory infectious diseases [86]. Severe vitamin D deficiency is frequently seen in critically ill patients and appears to be related to poor prognosis [87]. In older patients, severe vitamin D deficiency has been considered an independent predictor for community-acquired pneumonia [88], being also associated with increased risk of admission to an intensive care unit [89], and associated with mortality [90]. Moreover, vitamin D deficiency is shown to be associated with aggravation of lung inflammation, leading to acute respiratory distress syndrome (ARDS) with respiratory epithelium damage and hypoxia [91]. An inverse association between 25-OH-cholecalciferol levels and risk of acute respiratory failure in critically ill patients has been observed, being most convincingly significant for subjects with 25-OH-cholecalciferol $<25 \mathrm{nmol} / / \mathrm{L}$ [92].

Increasing experimental data on cells in vitro demonstrated beneficial effects of vitamin $\mathrm{D}$ as to pathogenetic mechanisms of respiratory viral infections. Thus, vitamin $\mathrm{D}$ treatment was shown to reduce respiratory syncytial virus (RSV) and rhinovirus (RV) replication in epithelial cells through enhancement of virus-induced interferon-stimulated genes [93] and synthesis of the antiviral protein LL-37 [94]. Treatment with 1,25(OH)-D improved respiratory-induced antiviral immune response to RV infections characterized by up-regulation of IL-8 and CXCL-10 (C-X-C motif chemokine ligand 10 also known as Interferon gamma-induced protein 10) production [95]. 
In addition, it was demonstrated that vitamin $\mathrm{D}$ is capable of reducing inflammatory response without alteration of antiviral activity and viral clearance in airway epithelial cells infected with RSV [96]. Furthermore, in view of high incidence of lung fibrosis as a characteristic sequela of COVID-19 [97], it is important to note that vitamin D prevented a TGF- $\beta 1$-induced profibrotic phenotype of lung cells [98].

However, no preventive effect of vitamin D supplementation on pneumonia was observed in three independent case-control studies [99], but the interpretation of these results should take into account the apparent lack of pre-existing vitamin D deficiency. Furthermore, the benefit of vitamin D replacement in an advanced stage of critical illness is controversial, as some studies do not show a benefit when it is administered late in the critical disease [100].

Vitamin D status can easily be determined as $25-\mathrm{OH}$-cholecalciferol in plasma. It follows that, in case of low status, $<50 \mathrm{nmol} / \mathrm{L}$ in plasma, vitamin D supplementation $\left(40 \mu \mathrm{g} \mathrm{D}_{3} /\right.$ day) could work as an approach for prevention of an aggressive course of the inflammation induced by this novel coronavirus. As for the preventive doses used, it is recommended that, on a long-term basis, the intake of vitamin D should be $\leq 100 \mu \mathrm{g}$ D3/day to avoid hypercalcuria with risk of renal stones, and also hypercalcemia [101].

\section{Discussion and Conclusions}

The direct evidence that the micronutrients zinc, selenium, and vitamin $\mathrm{D}$ might be involved in the course and outcome of the COVID-19 disease is observational and weak. However, based on experiences from treatments of SARS and other viral infections, we here underscored observations showing that nutritive supplements administered at an early stage of the infection were important for enhancing host resistance against RNA viral infections, which might also include severe COVID-19. We hypothesized that, in particular, increased resistance toward escalation of COVID-19 into the life-threatening cytokine release syndrome might be obtained (Figure 1). The nutritional status of the host has yet not been considered a crucial factor in severe viral infections, because the efficacy of nutrient supplementation when administered at the stage of advanced illness has been disappointing. Nevertheless, it is conceivable that a good nutritional status, if achieved in vulnerable population segments before escalation of the disease, would have immuno-enhancing and anti-inflammatory effects [102]. We are aware of the alleged therapeutic role of megadoses of vitamin C (6-8 g/day) in viral infections $[103,104]$, but, as this would be a pharmacological approach, we did not further discuss this in the present article. We considered the proposed intervention with, i.a., proteins and multivitamin solutions, given immediately after hospital admission to relieve the COVID-19 infection [105] to represent an interesting modification of our approach. However, further research and clinical trials are requested both on therapeutic and preventive roles of nutritive supplements. Based on the available literature, a reasonable presumption is that the pre-infectious status of zinc, selenium, and vitamin D might be of especial importance for the resistance against a progressive course of COVID-19.

Our recommendations are early outpatient nutritional intervention in SARS-CoV-2 exposed or high-risk subjects, preferably before specific and supportive treatment. It is tempting to suggest that that early nutritional interventions will be of particular significance for vulnerable segments of populations in developing countries. Such an approach is simple, cheap, and harmless. While high doses of the micronutrients might be needed to restore deficiencies, it is advisable to follow recommended upper tolerable intake levels for long-term intakes of the micronutrients. Parallel to any of the nutritional approaches, controlled studies on the efficacy of anti-viral and anti-inflammatory measures are of importance. To obtain general immunity, a COVID-19-related vaccine is highly warranted. 


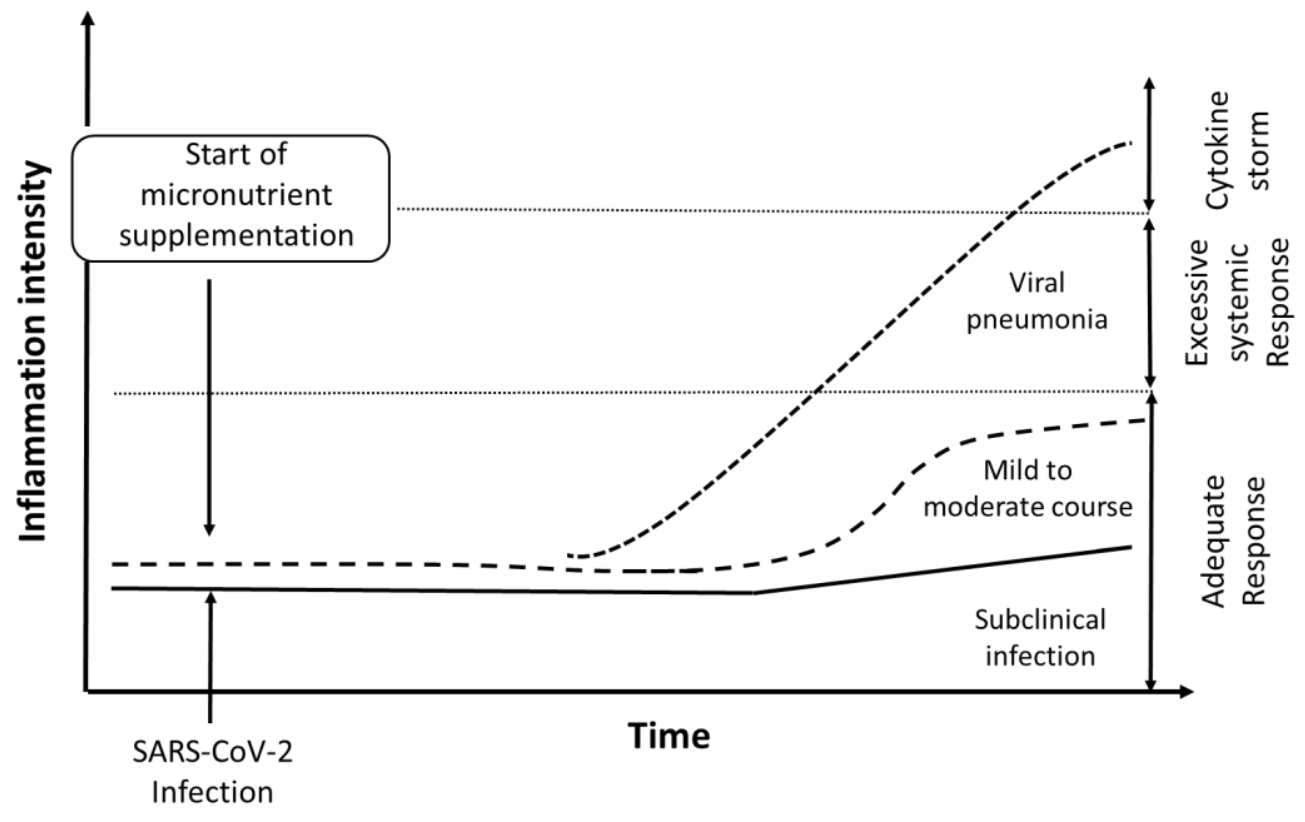

Figure 1. Hypothesized effect of supplements ( $\mathrm{Zn}, \mathrm{Se}$, and vitamin D) on intensity of inflammation in patients with COVID-19: A severe course of the disease, which may occur in cases with pre-infectious low-grade inflammation and inadequate status of micronutrients, is characterized by an escalation of the inflammation into a cytokine storm (dotted line). Supplementation with Se, Zn, and vitamins when given at an early stage after infection is anticipated to act protectively by improving immune reactivity and supporting adequate inflammatory response, leading to lower risk of cytokine storm and less severe course of COVID-19, as indicated by the dashed line.

Author Contributions: J.A. (Jan Aaseth) and J.A. (Jan Alexander) searched the literature and prepared the first draft. All authors contributed equally to writing additional text, review and editing of the manuscript. All authors have read and agreed to the published version of the manuscript.

Funding: This research received no external funding.

Acknowledgments: Innlandet Hospital Trust, Norway, is acknowledged for support.

Conflicts of Interest: One of the authors (U.A.) received support from Pharma Nord ApS, Denmark for a previous study. Authors J.A. (Jan Alexander), A.T., T.A.S., A.S., and J.A. (Jan Aaseth) declare no conflicts of interests.

\section{References}

1. Chen, Y.; Liu, Q.; Guo, D. Emerging coronaviruses: Genome structure, replication, and pathogenesis. J. Med. Virol. 2020, 92, 418-423. [CrossRef] [PubMed]

2. Li, Y.; Chen, M.; Cao, H.; Zhu, Y.; Zheng, J.; Zhou, H. Extraordinary GU-rich single-strand RNA identified from SARS coronavirus contributes an excessive innate immune response. Microbes Infect. 2013, 15, 88-95. [CrossRef] [PubMed]

3. Shimabukuro-Vornhagen, A.; Godel, P.; Subklewe, M.; Stemmler, H.J.; Schlosser, H.A.; Schlaak, M.; Kochanek, M.; Boll, B.; von Bergwelt-Baildon, M.S. Cytokine release syndrome. J. Immunother. Cancer 2018, 6, 56. [CrossRef]

4. Conti, P.; Ronconi, G.; Caraffa, A.; Gallenga, C.E.; Ross, R.; Frydas, I.; Kritas, S.K. Induction of pro-inflammatory cytokines (IL-1 and IL-6) and lung inflammation by Coronavirus-19 (COVI-19 or SARS-CoV-2): Anti-inflammatory strategies. J. Biol. Regul. Homeost. Agents 2020, 34. [CrossRef]

5. Arabi, Y.M.; Fowler, R.; Hayden, F.G. Critical care management of adults with community-acquired severe respiratory viral infection. Intensive Care Med. 2020, 46, 315-328. [CrossRef]

6. Russell, C.D.; Millar, J.E.; Baillie, J.K. Clinical evidence does not support corticosteroid treatment for 2019-nCoV lung injury. Lancet 2020, 395, 473-475. [CrossRef] 
7. Lew, T.W.; Kwek, T.K.; Tai, D.; Earnest, A.; Loo, S.; Singh, K.; Kwan, K.M.; Chan, Y.; Yim, C.F.; Bek, S.L.; et al. Acute respiratory distress syndrome in critically ill patients with severe acute respiratory syndrome. JAMA 2003, 290, 374-380. [CrossRef]

8. Weiss, P.; Murdoch, D.R. Clinical course and mortality risk of severe COVID-19. Lancet 2020, 395, 1014-1015. [CrossRef]

9. Zheng, Y.Y.; Ma, Y.T.; Zhang, J.Y.; Xie, X. COVID-19 and the cardiovascular system. Nat. Rev. Cardiol. 2020, 17, 259-260. [CrossRef]

10. Yang, Y.; Li, W.; Zhang, Q.; Zhang, L.; Cheung, T.; Xiang, Y.T. Mental health services for older adults in China during the COVID-19 outbreak. Lancet Psychiatry 2020, 7, e19. [CrossRef]

11. Hoffman, R. Micronutrient deficiencies in the elderly-Could ready meals be part of the solution? J. Nutr. Sci. 2017, 6, e2. [CrossRef] [PubMed]

12. Lipsitch, M.; Swerdlow, D.L.; Finelli, L. Defining the Epidemiology of Covid-19-Studies Needed. N. Engl. J. Med. 2020, 382, 1194-1196. [CrossRef] [PubMed]

13. Bjorklund, G.; Dadar, M.; Pivina, L.; Dosa, M.D.; Semenova, Y.; Aaseth, J. The role of zinc and copper in insulin resistance and diabetes mellitus. Curr. Med. Chem. 2019. [CrossRef] [PubMed]

14. Farrokhian, A.; Bahmani, F.; Taghizadeh, M.; Mirhashemi, S.M.; Aarabi, M.H.; Raygan, F.; Aghadavod, E.; Asemi, Z. Selenium Supplementation Affects Insulin Resistance and Serum hs-CRP in Patients with Type 2 Diabetes and Coronary Heart Disease. Horm. Metab. Res. 2016, 48, 263-268. [CrossRef] [PubMed]

15. Holmberg, S.; Rignell-Hydbom, A.; Lindh, C.H.; Jonsson, B.A.; Thelin, A.; Rylander, L. High levels of vitamin D associated with less ischemic heart disease-A nested case-control study among rural men in Sweden. Ann. Agric. Environ. Med. 2017, 24, 288-293. [CrossRef] [PubMed]

16. Grundy, S.M. Metabolic syndrome: Connecting and reconciling cardiovascular and diabetes worlds. J. Am. Coll. Cardiol. 2006, 47, 1093-1100. [CrossRef]

17. Sanada, F.; Taniyama, Y.; Muratsu, J.; Otsu, R.; Shimizu, H.; Rakugi, H.; Morishita, R. Source of Chronic Inflammation in Aging. Front. Cardiovasc Med. 2018, 5, 12. [CrossRef]

18. Maggini, S.; Pierre, A.; Calder, P.C. Immune Function and Micronutrient Requirements Change over the Life Course. Nutrients 2018, 10, 1531. [CrossRef]

19. Tainer, J.A.; Getzoff, E.D.; Richardson, J.S.; Richardson, D.C. Structure and mechanism of copper, zinc superoxide dismutase. Nature 1983, 306, 284-287. [CrossRef]

20. Maares, M.; Haase, H. Zinc and immunity: An essential interrelation. Arch. Biochem. Biophys 2016, 611, 58-65. [CrossRef]

21. Tuerk, M.J.; Fazel, N. Zinc deficiency. Curr. Opin. Gastroenterol. 2009, 25, 136-143. [CrossRef] [PubMed]

22. Barnett, J.B.; Hamer, D.H.; Meydani, S.N. Low zinc status: A new risk factor for pneumonia in the elderly? Nutr. Rev. 2010, 68, 30-37. [CrossRef] [PubMed]

23. Bonaventura, P.; Benedetti, G.; Albarede, F.; Miossec, P. Zinc and its role in immunity and inflammation. Autoimmun Rev. 2015, 14, 277-285. [CrossRef] [PubMed]

24. Kulik, L.; Maywald, M.; Kloubert, V.; Wessels, I.; Rink, L. Zinc deficiency drives Th17 polarization and promotes loss of Treg cell function. J. Nutr. Biochem. 2019, 63, 11-18. [CrossRef]

25. Mariani, E.; Cattini, L.; Neri, S.; Malavolta, M.; Mocchegiani, E.; Ravaglia, G.; Facchini, A. Simultaneous evaluation of circulating chemokine and cytokine profiles in elderly subjects by multiplex technology: Relationship with zinc status. Biogerontology 2006, 7, 449-459. [CrossRef]

26. Finzi, E. Treatment of SARS-CoV-2 with high dose oral zinc salts: A report on four patients. Int. J. Infect. Dis. 2020. [CrossRef]

27. Sattar, Y.; Connerney, M.; Rauf, H.; Saini, M.; Ullah, W.; Mamtani, S.; Syed, U.; Luddington, S.; Walfish, A. Three Cases of COVID-19 Disease With Colonic Manifestations. Am. J. Gastroenterol. 2020, 115, 948-950. [CrossRef]

28. Lazzerini, M.; Wanzira, H. Oral zinc for treating diarrhoea in children. Cochrane Database Syst Rev. 2016, 12, CD005436. [CrossRef]

29. Skalny, A.V.; Rink, L.; Ajsuvakova, O.P.; Aschner, M.; Gritsenko, V.A.; Alekseenko, S.I.; Svistunov, A.A.; Petrakis, D.; Spandidos, D.A.; Aaseth, J.; et al. Zinc and respiratory tract infections: Perspectives for COVID19 (Review). Int. J. Mol. Med. 2020, 46, 17-26. [CrossRef]

30. Lassi, Z.S.; Moin, A.; Bhutta, Z.A. Zinc supplementation for the prevention of pneumonia in children aged 2 months to 59 months. Cochrane Database Syst Rev. 2016, 12, CD005978. [CrossRef] 
31. Haider, B.A.; Lassi, Z.S.; Ahmed, A.; Bhutta, Z.A. Zinc supplementation as an adjunct to antibiotics in the treatment of pneumonia in children 2 to 59 months of age. Cochrane Database Syst Rev. 2011. [CrossRef]

32. Bhatnagar, S.; Wadhwa, N.; Aneja, S.; Lodha, R.; Kabra, S.K.; Natchu, U.C.; Sommerfelt, H.; Dutta, A.K.; Chandra, J.; Rath, B.; et al. Zinc as adjunct treatment in infants aged between 7 and 120 days with probable serious bacterial infection: A randomised, double-blind, placebo-controlled trial. Lancet 2012, 379, 2072-2078. [CrossRef]

33. Science, M.; Johnstone, J.; Roth, D.E.; Guyatt, G.; Loeb, M. Zinc for the treatment of the common cold: A systematic review and meta-analysis of randomized controlled trials. CMAJ 2012, 184, E551-E561. [CrossRef]

34. Hemila, H. Zinc lozenges may shorten the duration of colds: A systematic review. Open Respir. Med. J. 2011, 5, 51-58. [CrossRef] [PubMed]

35. Basnet, S.; Mathisen, M.; Strand, T.A. Oral zinc and common childhood infections-An update. J. Trace Elem. Med. Biol. 2015, 31, 163-166. [CrossRef] [PubMed]

36. Ko, W.S.; Guo, C.H.; Hsu, G.S.; Chiou, Y.L.; Yeh, M.S.; Yaun, S.R. The effect of zinc supplementation on the treatment of chronic hepatitis C patients with interferon and ribavirin. Clin. Biochem. 2005, 38, 614-620. [CrossRef]

37. te Velthuis, A.J.; van den Worm, S.H.; Sims, A.C.; Baric, R.S.; Snijder, E.J.; van Hemert, M.J. Zn(2+) inhibits coronavirus and arterivirus RNA polymerase activity in vitro and zinc ionophores block the replication of these viruses in cell culture. PLoS Pathog. 2010, 6, e1001176. [CrossRef]

38. Iyigundogdu, Z.U.; Demir, O.; Asutay, A.B.; Sahin, F. Developing Novel Antimicrobial and Antiviral Textile Products. Appl. Biochem. Biotechnol. 2017, 181, 1155-1166. [CrossRef]

39. Zhang, L.; Liu, Y. Potential interventions for novel coronavirus in China: A systematic review. J. Med. Virol. 2020, 92, 479-490. [CrossRef]

40. EU Scientific Committee on Food. Opinion of the Scientific Committee on Food on the Tolerable Upper Intake Level of Zinc; European Commission: Brussels, Belgium, 2003.

41. Fairweather-Tait, S.J.; Bao, Y.; Broadley, M.R.; Collings, R.; Ford, D.; Hesketh, J.E.; Hurst, R. Selenium in human health and disease. Antioxid Redox Signal. 2011, 14, 1337-1383. [CrossRef]

42. Beck, M.A.; Matthews, C.C. Micronutrients and host resistance to viral infection. Proc. Nutr. Soc. 2000, 59, 581-585. [CrossRef] [PubMed]

43. Long, J.; Liu, Y.; Zhou, X.; He, L. Dietary Serine Supplementation Regulates Selenoprotein Transcription and Selenoenzyme Activity in Pigs. Biol. Trace Elem. Res. 2020. [CrossRef] [PubMed]

44. Zhang, J.; Taylor, E.W.; Bennett, K.; Saad, R.; Rayman, M.P. Association between regional selenium status and reported outcome of COVID-19 cases in China. Am. J. Clin. Nutr. 2020, 111, 1297-1299. [CrossRef]

45. Moghaddam, A.; Heller, R.A.; Sun, Q.; Seelig, J.; Cherkezov, A.; Seibert, L.; Hackler, J.; Seemann, P.; Diegmann, J.; Pilz, M.; et al. Selenium Deficiency Is Associated with Mortality Risk from COVID-19. Nutrients 2020, 12, 2098. [CrossRef]

46. Gordon, D.E.; Jang, G.M.; Bouhaddou, M.; Xu, J.; Obernier, K.; White, K.M.; O’Meara, M.J.; Rezelj, V.V.; Guo, J.Z.; Swaney, D.L.; et al. A SARS-CoV-2 protein interaction map reveals targets for drug repurposing. Nature 2020, 583, 459-468. [CrossRef] [PubMed]

47. Seale, L.A.; Torres, D.J.; Berry, M.J.; Pitts, M.W. A role for selenium-dependent GPX1 in SARS-CoV-2 virulence. Am. J. Clin. Nutr. 2020. [CrossRef] [PubMed]

48. Sies, H.; Parnham, M.J. Potential therapeutic use of ebselen for COVID-19 and other respiratory viral infections. Free Radic. Biol. Med. 2020, 156, 107-112. [CrossRef]

49. Vavougios, G.D. Selenium-Associated gene signatures within the SARS-CoV-2-Host genomic interaction interface. Free Radic. Biol. Med. 2020. [CrossRef]

50. Guillin, O.M.; Vindry, C.; Ohlmann, T.; Chavatte, L. Selenium, Selenoproteins and Viral Infection. Nutrients 2019, 11, 2101. [CrossRef]

51. Pearson, H.; Clarke, T.; Abbott, A.; Knight, J.; Cyranoski, D. SARS: What have we learned? Nature 2003, 424, 121-126. [CrossRef]

52. Harthill, M. Review: Micronutrient selenium deficiency influences evolution of some viral infectious diseases. Biol. Trace Elem. Res. 2011, 143, 1325-1336. [CrossRef] [PubMed] 
53. Alehagen, U.; Alexander, J.; Aaseth, J.; Larsson, A. Decrease in inflammatory biomarker concentration by intervention with selenium and coenzyme Q10: A subanalysis of osteopontin, osteoprotergerin, TNFr1, TNFr2 and TWEAK. J. Inflamm. 2019, 16, 5. [CrossRef] [PubMed]

54. Avery, J.C.; Hoffmann, P.R. Selenium, Selenoproteins, and Immunity. Nutrients 2018, 10, 1203. [CrossRef] [PubMed]

55. Beck, M.A.; Nelson, H.K.; Shi, Q.; Van Dael, P.; Schiffrin, E.J.; Blum, S.; Barclay, D.; Levander, O.A. Selenium deficiency increases the pathology of an influenza virus infection. FASEB J. 2001, 15, 1481-1483. [CrossRef] [PubMed]

56. Beck, M.A. Selenium as an antiviral agent. In Selenium. Its Molecular Biology and Role in Human Health; Hatfield, D.L., Ed.; Kluwer Academic Publishers: Dordrect, The Netherlands, 2001; pp. 235-245.

57. Yu, L.; Sun, L.; Nan, Y.; Zhu, L.Y. Protection from H1N1 influenza virus infections in mice by supplementation with selenium: A comparison with selenium-deficient mice. Biol. Trace Elem. Res. 2011, 141, $254-261$. [CrossRef] [PubMed]

58. Shojadoost, B.; Kulkarni, R.R.; Yitbarek, A.; Laursen, A.; Taha-Abdelaziz, K.; Negash Alkie, T.; Barjesteh, N.; Quinteiro-Filho, W.M.; Smith, T.K.; Sharif, S. Dietary selenium supplementation enhances antiviral immunity in chickens challenged with low pathogenic avian influenza virus subtype H9N2. Vet. Immunol. Immunopathol. 2019, 207, 62-68. [CrossRef] [PubMed]

59. Ivory, K.; Prieto, E.; Spinks, C.; Armah, C.N.; Goldson, A.J.; Dainty, J.R.; Nicoletti, C. Selenium supplementation has beneficial and detrimental effects on immunity to influenza vaccine in older adults. Clin. Nutr. 2017, 36, 407-415. [CrossRef] [PubMed]

60. Steinbrenner, H.; Al-Quraishy, S.; Dkhil, M.A.; Wunderlich, F.; Sies, H. Dietary selenium in adjuvant therapy of viral and bacterial infections. Adv. Nutr. 2015, 6, 73-82. [CrossRef]

61. Kafai, M.R.; Ganji, V. Sex, age, geographical location, smoking, and alcohol consumption influence serum selenium concentrations in the USA: Third National Health and Nutrition Examination Survey, 1988-1994. J. Trace Elem. Med. Biol. 2003, 17, 13-18. [CrossRef]

62. Alehagen, U.; Johansson, P.; Bjornstedt, M.; Rosen, A.; Post, C.; Aaseth, J. Relatively high mortality risk in elderly Swedish subjects with low selenium status. Eur. J. Clin. Nutr. 2016, 70, 91-96. [CrossRef]

63. Vogt, B.L.; Richie, J.P., Jr. Glutathione depletion and recovery after acute ethanol administration in the aging mouse. Biochem. Pharmacol. 2007, 73, 1613-1621. [CrossRef] [PubMed]

64. Lang, C.A.; Naryshkin, S.; Schneider, D.L.; Mills, B.J.; Lindeman, R.D. Low blood glutathione levels in healthy aging adults. J. Lab. Clin. Med. 1992, 120, 720-725. [PubMed]

65. Lang, C.A.; Mills, B.J.; Mastropaolo, W.; Liu, M.C. Blood glutathione decreases in chronic diseases. J. Lab. Clin. Med. 2000, 135, 402-405. [CrossRef] [PubMed]

66. Chaves, F.J.; Mansego, M.L.; Blesa, S.; Gonzalez-Albert, V.; Jimenez, J.; Tormos, M.C.; Espinosa, O.; Giner, V.; Iradi, A.; Saez, G.; et al. Inadequate cytoplasmic antioxidant enzymes response contributes to the oxidative stress in human hypertension. Am. J. Hypertens. 2007, 20, 62-69. [CrossRef] [PubMed]

67. Khomich, O.A.; Kochetkov, S.N.; Bartosch, B.; Ivanov, A.V. Redox Biology of Respiratory Viral Infections. Viruses 2018, 10, 392. [CrossRef]

68. Shetty, R.; Udupa, N.; Mutalik, S.; Kulkarni, V.; Rao, V. Mechanisms and Therapeutics of N-acetylcysteine: A Recent Update. Res. J. Pharm. Technol. 2019, 12, 2584-2588. [CrossRef]

69. Lai, K.Y.; Ng, W.Y.; Osburga Chan, P.K.; Wong, K.F.; Cheng, F. High-dose N-acetylcysteine therapy for novel H1N1 influenza pneumonia. Ann. Intern. Med. 2010, 152, 687-688. [CrossRef]

70. Horowitz, R.I.; Freeman, P.R.; Bruzzese, J. Efficacy of glutathione therapy in relieving dyspnea associated with COVID-19 pneumonia: A report of 2 cases. Respir Med. Case Rep. 2020. [CrossRef]

71. Alehagen, U.; Lindahl, T.L.; Aaseth, J.; Svensson, E.; Johansson, P. Levels of sP-selectin and hs-CRP Decrease with Dietary Intervention with Selenium and Coenzyme Q10 Combined: A Secondary Analysis of a Randomized Clinical Trial. PLoS ONE 2015, 10, e0137680. [CrossRef]

72. Alehagen, U.; Alexander, J.; Aaseth, J. Supplementation with Selenium and Coenzyme Q10 Reduces Cardiovascular Mortality in Elderly with Low Selenium Status. A Secondary Analysis of a Randomised Clinical Trial. PLoS ONE 2016, 11, e0157541. [CrossRef]

73. Zhai, J.; Bo, Y.; Lu, Y.; Liu, C.; Zhang, L. Effects of Coenzyme Q10 on Markers of Inflammation: A Systematic Review and Meta-Analysis. PLoS ONE 2017, 12, e0170172. [CrossRef] [PubMed] 
74. Kalen, A.; Appelkvist, E.L.; Dallner, G. Age-related changes in the lipid compositions of rat and human tissues. Lipids 1989, 24, 579-584. [CrossRef] [PubMed]

75. Broman, L.M.; Bernardson, A.; Bursell, K.; Wernerman, J.; Flaring, U.; Tjader, I. Serum selenium in critically ill patients: Profile and supplementation in a depleted region. Acta Anaesthesiol. Scand. 2020, 64, 803-809. [CrossRef] [PubMed]

76. Manzanares, W.; Lemieux, M.; Elke, G.; Langlois, P.L.; Bloos, F.; Heyland, D.K. High-dose intravenous selenium does not improve clinical outcomes in the critically ill: A systematic review and meta-analysis. Crit. Care 2016, 20, 356. [CrossRef]

77. EU Scientific Committee on Food. Opinion of the Scientific Committee on Food on the Tolerable Upper Intake Level of Selenium; European Commission: Brussels, Belgium, 2000.

78. Liu, L.C.; Voors, A.A.; van Veldhuisen, D.J.; van der Veer, E.; Belonje, A.M.; Szymanski, M.K.; Sillje, H.H.; van Gilst, W.H.; Jaarsma, T.; de Boer, R.A. Vitamin D status and outcomes in heart failure patients. Eur. J. Heart Fail. 2011, 13, 619-625. [CrossRef]

79. Tangpricha, V.; Pearce, E.N.; Chen, T.C.; Holick, M.F. Vitamin D insufficiency among free-living healthy young adults. Am. J. Med. 2002, 112, 659-662. [CrossRef]

80. Holick, M.F. The vitamin D deficiency pandemic: Approaches for diagnosis, treatment and prevention. Rev. Endocr. Metab. Disord. 2017, 18, 153-165. [CrossRef] [PubMed]

81. Ilie, P.C.; Stefanescu, S.; Smith, L. The role of vitamin D in the prevention of coronavirus disease 2019 infection and mortality. Aging Clin. Exp. Res. 2020, 32, 1195-1198. [CrossRef] [PubMed]

82. Rhodes, J.M.; Subramanian, S.; Laird, E.; Kenny, R.A. Editorial: Low population mortality from COVID-19 in countries south of latitude 35 degrees North supports vitamin D as a factor determining severity. Aliment. Pharmacol. Ther. 2020, 51, 1434-1437. [CrossRef] [PubMed]

83. Chang, T.S.; Ding, Y.; Freund, M.K.; Johnson, R.; Schwarz, T.; Yabu, J.M.; Hazlett, C.; Chiang, J.N.; Wulf, A.; Geschwind, D.H.; et al. Prior diagnoses and medications as risk factors for COVID-19 in a Los Angeles Health System. medRxiv 2020. [CrossRef]

84. Panagiotou, G.; Tee, S.A.; Ihsan, Y.; Athar, W.; Marchitelli, G.; Kelly, D.; Boot, C.S.; Stock, N.; Macfarlane, J.; Martineau, A.R.; et al. Low serum 25-hydroxyvitamin D (25[OH]D) levels in patients hospitalised with COVID-19 are associated with greater disease severity. Clin. Endocrinol. 2020. [CrossRef] [PubMed]

85. Mendy, A.; Apewokin, S.; Wells, A.A.; Morrow, A.L. Factors Associated with Hospitalization and Disease Severity in a Racially and Ethnically Diverse Population of COVID-19 Patients. medRxiv 2020. [CrossRef]

86. Hughes, D.A.; Norton, R. Vitamin D and respiratory health. Clin. Exp. Immunol. 2009, 158, 20-25. [CrossRef] [PubMed]

87. de Haan, K.; Groeneveld, A.B.; de Geus, H.R.; Egal, M.; Struijs, A. Vitamin D deficiency as a risk factor for infection, sepsis and mortality in the critically ill: Systematic review and meta-analysis. Crit. Care 2014, 18, 660. [CrossRef] [PubMed]

88. Lu, D.; Zhang, J.; Ma, C.; Yue, Y.; Zou, Z.; Yu, C.; Yin, F. Link between community-acquired pneumonia and vitamin D levels in older patients. Z. Gerontol. Geriatr. 2018, 51, 435-439. [CrossRef] [PubMed]

89. Remmelts, H.H.; van de Garde, E.M.; Meijvis, S.C.; Peelen, E.L.; Damoiseaux, J.G.; Grutters, J.C.; Biesma, D.H.; Bos, W.J.; Rijkers, G.T. Addition of vitamin D status to prognostic scores improves the prediction of outcome in community-acquired pneumonia. Clin. Infect. Dis. 2012, 55, 1488-1494. [CrossRef] [PubMed]

90. Holter, J.C.; Ueland, T.; Norseth, J.; Brunborg, C.; Froland, S.S.; Husebye, E.; Aukrust, P.; Heggelund, L. Vitamin D Status and Long-Term Mortality in Community-Acquired Pneumonia: Secondary Data Analysis from a Prospective Cohort. PLoS ONE 2016, 11, e0158536. [CrossRef]

91. Dancer, R.C.; Parekh, D.; Lax, S.; D’Souza, V.; Zheng, S.; Bassford, C.R.; Park, D.; Bartis, D.G.; Mahida, R.; Turner, A.M.; et al. Vitamin D deficiency contributes directly to the acute respiratory distress syndrome (ARDS). Thorax 2015, 70, 617-624. [CrossRef]

92. Thickett, D.R.; Moromizato, T.; Litonjua, A.A.; Amrein, K.; Quraishi, S.A.; Lee-Sarwar, K.A.; Mogensen, K.M.; Purtle, S.W.; Gibbons, F.K.; Camargo, C.A., Jr.; et al. Association between prehospital vitamin D status and incident acute respiratory failure in critically ill patients: A retrospective cohort study. BMJ Open Respir Res. 2015, 2, e000074. [CrossRef]

93. Telcian, A.G.; Zdrenghea, M.T.; Edwards, M.R.; Laza-Stanca, V.; Mallia, P.; Johnston, S.L.; Stanciu, L.A. Vitamin D increases the antiviral activity of bronchial epithelial cells in vitro. Antiviral Res. 2017, 137, 93-101. [CrossRef] 
94. Schogler, A.; Muster, R.J.; Kieninger, E.; Casaulta, C.; Tapparel, C.; Jung, A.; Moeller, A.; Geiser, T.; Regamey, N.; Alves, M.P. Vitamin D represses rhinovirus replication in cystic fibrosis cells by inducing LL-37. Eur. Respir. J. 2016, 47, 520-530. [CrossRef] [PubMed]

95. Brockman-Schneider, R.A.; Pickles, R.J.; Gern, J.E. Effects of vitamin D on airway epithelial cell morphology and rhinovirus replication. PLoS ONE 2014, 9, e86755. [CrossRef] [PubMed]

96. Hansdottir, S.; Monick, M.M.; Lovan, N.; Powers, L.; Gerke, A.; Hunninghake, G.W. Vitamin D decreases respiratory syncytial virus induction of NF-kappaB-linked chemokines and cytokines in airway epithelium while maintaining the antiviral state. J. Immunol. 2010, 184, 965-974. [CrossRef] [PubMed]

97. Bernheim, A.; Mei, X.; Huang, M.; Yang, Y.; Fayad, Z.A.; Zhang, N.; Diao, K.; Lin, B.; Zhu, X.; Li, K.; et al. Chest CT Findings in Coronavirus Disease-19 (COVID-19): Relationship to Duration of Infection. Radiology 2020. [CrossRef] [PubMed]

98. Ramirez, A.M.; Wongtrakool, C.; Welch, T.; Steinmeyer, A.; Zugel, U.; Roman, J. Vitamin D inhibition of pro-fibrotic effects of transforming growth factor beta1 in lung fibroblasts and epithelial cells. J. Steroid Biochem. Mol. Biol. 2010, 118, 142-150. [CrossRef]

99. Remmelts, H.H.; Spoorenberg, S.M.; Oosterheert, J.J.; Bos, W.J.; de Groot, M.C.; van de Garde, E.M. The role of vitamin D supplementation in the risk of developing pneumonia: Three independent case-control studies. Thorax 2013, 68, 990-996. [CrossRef]

100. Ingels, C.; Vanhorebeek, I.; Van Cromphaut, S.; Wouters, P.J.; Derese, I.; Dehouwer, A.; Moller, H.J.; Hansen, T.K.; Billen, J.; Mathieu, C.; et al. Effect of Intravenous 25OHD Supplementation on Bone Turnover and Inflammation in Prolonged Critically Ill Patients. Horm. Metab. Res. 2020, 52, 168-178. [CrossRef]

101. Scientific Opinion on the Tolerable Upper Intake Level of vitamin D. EFSA J. 2012, 10, 2813. [CrossRef]

102. Calder, P.C.; Carr, A.C.; Gombart, A.F.; Eggersdorfer, M. Optimal Nutritional Status for a Well-Functioning Immune System Is an Important Factor to Protect against Viral Infections. Nutrients 2020, 12, 1181. [CrossRef]

103. Hemila, H.; Chalker, E. Vitamin C as a Possible Therapy for COVID-19. Infect. Chemother 2020, 52, $222-223$. [CrossRef]

104. Hemila, H. Vitamin C and Infections. Nutrients 2017, 9, 339. [CrossRef] [PubMed]

105. Caccialanza, R.; Laviano, A.; Lobascio, F.; Montagna, E.; Bruno, R.; Ludovisi, S.; Corsico, A.G.; Di Sabatino, A.; Belliato, M.; Calvi, M.; et al. Early nutritional supplementation in non-critically ill patients hospitalized for the 2019 novel coronavirus disease (COVID-19): Rationale and feasibility of a shared pragmatic protocol. Nutrition 2020, 74, 110835. [CrossRef] [PubMed] 